\title{
Standardization of Specific and Non-Specific Parameters of Propolis Extract as Raw Material for Herbal Product
}

\author{
Yandi Syukri ${ }^{1{ }^{* *}}$, Ririk Purwati ${ }^{1}$, Nadia Hazami ${ }^{1}$, Hady Anshory Tahmid ${ }^{1}$, Annisa Fitria ${ }^{1}$ \\ 1 Department of Pharmacy, Faculty of Mathematics and Natural Sciences, Universitas Islam \\ Indonesia \\ * Corresponding author: yandisyukri@uii.ac.id
}

Received: 1 Januari 2020; Accepted: 13 Jauary 2020; Published: 5 February 2020

\begin{abstract}
This study aims to standardize the specific and non-specific parameters of propolis extract originating from East Java, Indonesia, to fulfil the requirements as a herbal raw material. Standardization was carried out on propolis ethanol extract taken at three different harvesting times. Standardization was carried out on specific parameters including the content of dissolved compounds, chemical content of extracts and chromatogram patterns, while the non-specific parameters of the extract included water content, ash content residue, density, microbial contamination, and heavy metal contamination. Specific extract parameters showed that the water-soluble extract content was 2.1-3.5\%; levels of ethanol-soluble extract $62.00-84.00 \%$; total flavonoid levels of $0.015-0.072 \mathrm{mg}$ ER/g; and total phenol content of 0.0039 $0.0053 \mathrm{mg} \mathrm{ER} / \mathrm{g}$. Non-specific parameters indicate that the water content is $10.72-10.90 \%$; drying losses $10.05-10.63 \%$; total ash content of $0.08-0.65 \%$, density of $0.88-0.89 \mathrm{~g} / \mathrm{mL} ; \mathrm{Pb}$ levels from $6.55-9.01 \mathrm{mg} / \mathrm{kg}$; $\mathrm{Cd}$ content of $0.50-1.22 \mathrm{mg} / \mathrm{kg}, \mathrm{Cu}$ content of $0.82-1.13 \mathrm{mg} / \mathrm{kg}$; the total plate number is 10 colonies $/ \mathrm{g}$ and the yeast fungus number is 10 colonies/g. It can be concluded that propolis extract from the East Java region of Indonesia fulfils the requirements as a raw material for herbal products in Indonesia.
\end{abstract}

Keywords: standardization, propolis, specific and non-specific parameter, herbal product

\section{Introduction}

Medicinal products from natural ingredients are a promising source in the discovery of medicinal raw materials. Researchers have published that propolis is one of the most potential natural ingredients to be developed because the ingredients contained in it have many health benefits [1]. Propolis is a resin material collected by bees from the sap of trees, leaves and flowers that is useful for protecting beehives against bacterial and fungal infections. Propolis has a complex chemical composition and differs depending on the source. Phenolic acid and flavonoids are essential compounds contained in propolis which have biological activity [2].

Propolis is currently very popular because it is widely used as a health food and alternative medicine in various countries. Chemical compounds that have been identified from propolis are polyphenols, flavanones, flavonols, flavones, dihydro flavonols, chalcones, phenolic acids and their esters, monoterpenes, sesquiterpenes, diterpenes and triterpenes, steroids, aromatic aldehydes, alcohols, naphthalene and stilb derivatives, monoterpenes, sesquiterpenes, diterpenes and triterpenes, steroids, aromatic aldehydes, alcohols, naphthalene and stilbene derivatives [3]. Propolis has anti-inflammatory activity from flavonoid and phenols compounds [4,5] and Artepilin C compounds contained therein [6]. It has also been studied that propolis originating from Northern Argentina [7] and Brazil [8] have immunomodulatory activities. Other biological activities that have been studied from propolis are antibacterial, antifungal, diabetes mellitus, and antioxidants [9-11].

Propolis is currently widely used as an additive for sweets and biopharmaceutical products and is used as a cosmetic ingredient. It also functions as a preservative for food and beverage products [12]. Based on a study of its biological effects, many consumers are interested in consuming propolis products. Recently, several daily products containing propolis with various compositions for treatment have been 
available in the market such as wound medicine, toothpaste and food supplements (antioxidants, immunity and energy enhancers). However, because the chemical composition of propolis varies significantly by geographic location, the use of drugs and nutraceuticals from propolis products must be certified by an official regulatory body. For this reason, an assessment of the minimum requirements to start research as a drug raw material is required by standardizing the propolis raw material [13]. This study aims to standardize propolis extract raw materials, including specific and non-specific parameters of propolis originating from East Java, Indonesia, to meet the requirements as herbal raw materials.

\section{Materials and Methods}

Materials

Propolis was obtained from bee breeding using Apis malifera hives 3 times during JanuaryDecember 2017 in East Java. Other ingredients are Caffeic Acid Phenethyl Ester (CAPE) and routines obtained from Sigma Aldrich, Saboraud Dextrose Agar (SDA) (Oxoid TM), Plate Count Agar (PCA) (Oxoid TM), peptone water (Oxoid TM). Nitric acid, perchloric acid and sulfuric acid, formic acid, chloroform, ethanol, $\mathrm{AlCl}_{3}, \mathrm{NaOH}$ and the Folin-Ciocalteu reagent were obtained from Merck (Germany).

Methods

Propolis Extract Preparation

A total of $100 \mathrm{~g}$ of propolis was extracted with $500 \mathrm{~mL} 96 \%$ ethanol which was carried out at room temperature $\left(25^{\circ} \mathrm{C}\right)$ for 30 minutes. The solution is filtered to produce a crude extract overnight in the freezer $\left(-18{ }^{\circ} \mathrm{C}\right)$ to precipitate the wax. Then, the extract is separated from the wax using a separating funnel, and the supernatant is evaporated to dryness in a rotary evaporator at $40^{\circ} \mathrm{C}$ [14].

Standardization of Specific Parameters

Standardization was carried out on specific parameters, including organoleptic content of dissolved compounds, chemical content of extracts and chromatogram patterns [15]. The sample was carried out on 3 samples taken 3 times during January-December 2017.

Organoleptic

The organoleptic test is conducted by observing the shape, colour, smell and taste of propolis extract.

The Content of Dissolved Compounds

The water-soluble compound test is carried out by adding $20 \mathrm{~mL}$ of water-chloroform $\mathrm{LP}$ then macerated for 24 hours while shaken repeatedly for the first 6 hours. Then, it is allowed to stand for approximately 18 hours and filtered out the propolis extract. Followed by evaporation of filtrate as much as $4 \mathrm{ml}$ to dry, the residue is heated at $105{ }^{\circ} \mathrm{C}$ until a permanent weight occurs. Next calculated concentration of dissolved compounds in water to the weight of the initial extract in per cent. Determination of concentration of ethanol-soluble compounds is conducted by adding $20 \mathrm{ml}$ of ethanol (95\%), then macerated for 24 hours while shaking it repeatedly for the first 6 hours, left for 18 hours. Quick filtering is carried out to avoid the evaporation of ethanol, after that, it is continued again by evaporation of $4 \mathrm{ml}$ of filtrate using a steaming cup that has been tasted too dry, then heat the residue at $105^{\circ} \mathrm{C}$ until there is a fixed weight. The concentration of compound soluble in ethanol $(95 \%)$ was calculated by the weight of the initial extract in per cent.

Analysis of flavonoids in extracts. Analysis of total flavonoid concentration was carried out to determine the content of flavonoid compounds in propolis extract quantitatively. Propolis extract weighed as much as 1 gram, then added $30 \mathrm{~mL}$ of $70 \%$ ethanol and let stand for 24 hours. As much as $0.4 \mathrm{~mL}$ of propolis extract added $0.2 \mathrm{~mL}$ of $5 \% \mathrm{AlCl}_{3}$, then added $4 \mathrm{~mL}$ of $1 \mathrm{M} \mathrm{NaOH}$ and $70 \%$ ethanol to the markings in the $10 \mathrm{~mL}$ volumetric flask, allowed to stand for 15 minutes. The absorbance was measured at a wavelength $(\lambda)$ of $425 \mathrm{~nm}$ with absolute ethanol as a control. Routine solution was used as a calibration curve with a concentration of $200 \mu \mathrm{g} / \mathrm{mL} ; 250 \mu \mathrm{g} / \mathrm{mL} ; 300 \mu \mathrm{g} / \mathrm{mL} ; 400 \mu \mathrm{g} / \mathrm{mL} ; 500 \mu \mathrm{g} / \mathrm{mL} ; 600 \mu \mathrm{g} / \mathrm{mL}$; and $700 \mu \mathrm{g} / \mathrm{mL}$. The total of the flavonoid content of the test sample is expressed as mg equivalent routine/g (mg ER/g), i.e. the equality of routine milligrams in 1 gram of sample. The following is calculated the total number of flavonoids in each sample. The analysis of total phenolic concentration was carried out to determine the content of phenol groups in propolis extract quantitatively. A total of $10 \mu \mathrm{L}$ extract was then oxidized with $0.5 \mathrm{~mL} 2 \mathrm{M}$ Folin-Ciocalteu reagent, then neutralized by the addition of 2 $\mathrm{mL} \mathrm{Na} \mathrm{CO}_{3} 1 \%$, allowed to stand for 2 hours in a dark room and absorbance measured at the wavelength 
( $\lambda$ ) $765 \mathrm{~nm}$ using a UV-visible spectrophotometer (Shimadzu UV 1800, Japan). Caffeic Acid Phenethyl Ester (CAPE) is used as a calibration curve with a concentration series of $50 \mu \mathrm{g} / \mathrm{mL} ; 100 \mu \mathrm{g} \mathrm{mL} ; 200$ $\mu \mathrm{g} / \mathrm{mL} ; 300 \mu \mathrm{g} / \mathrm{mL} ; 400 \mu \mathrm{g} / \mathrm{mL} ; 500 \mu \mathrm{g} / \mathrm{mL} ; 600 \mu \mathrm{g} / \mathrm{mL}$; and $700 \mu \mathrm{g} / \mathrm{mL}$. The total phenol content of the test sample is expressed as mg equivalent CAPE / $\mathrm{g}(\mathrm{mg}$ ECAPE/g), i.e. the number of milligrams of gallic acid equivalents in 1 gram of sample. The following is calculated the total number of flavonoids in each sample.

\section{Chromatogram pattern}

Propolis extract was dissolved with 70\% ethanol and used caffeic acid as a standard, the stationary phase used was silica gel $60 \mathrm{~F}_{256}$, and the mobile phase used a ratio between chloroform: ethyl acetate, and $98 \%$ formic acid (7:2:1), then dosed on a silica plate and then sprayed using aluminium chloride. The test results can be seen through UV254 nm light.

Standardization of non-specific parameters

Testing the non-specific parameters of the extract include specific gravity, water content, ash content, residual solvents, microbial contamination, and heavy metal contamination [15].

Determination of water content

Samples were weighed 1 gram, heated in the oven for 5 hours at $105^{\circ} \mathrm{C}$ then weighed. Next, the per cent of water content to the weight of the initial sample is calculated.

\section{Determination of ash content}

One gram of extract $\left(\mathrm{B}_{1}\right)$ was weighed into a silicate crucible which had previously been flattened and tamed $\left(\mathrm{B}_{0}\right)$. Then the extract is slowly incubated (at a temperature of $600{ }^{\circ} \mathrm{C} 25^{\circ} \mathrm{C}$ ) until the charcoal is used up, then cooled in a desiccator, and weighed ashes $\left(\mathrm{B}_{2}\right)$ against the weight of the initial sample.

\section{Determination of metal contamination}

The concentration of lead $(\mathrm{Pb})$, cadmium $(\mathrm{Cd})$ and copper $(\mathrm{Cu})$ were determined by wet destruction method. Weighed 1 gram of extract, added with $10 \mathrm{~mL}$ thick, then heated until half the volume was obtained. Refrigerated thick extract that has been achieved, then added $5 \mathrm{~mL}$, heated until white smoke disappears, allowed to cool and rinsed using distilled water, then filtered into a $50-\mathrm{mL}$ volumetric flask, and added distilled water to the boundary markers, after which samples were measured by using atomic absorption spectroscopy (PinAAcle TM 900T).

Determination of microbial contamination

Contamination of the total plate number (TPN) is done by weighing 10 grams of extract and adding $90 \mathrm{~mL}$ of a peptone water diluent solution that has been sterilized (dilution) then transferred to a sterile bag and then the sample is in a sterile bag while homogenized, further diluting. This test uses the Plate Count Agar (PCA) as the agar medium. PCA was dissolved with distilled water, then heated to a temperature of $45{ }^{\circ} \mathrm{C}$ until bubbling, then put as much as $20 \mathrm{~mL}$, then sterilized at $121^{\circ} \mathrm{C}$ for 15 minutes. A total of $1000 \mu \mathrm{L}(1 \mathrm{~mL})$ from each dilution of the solution containing a warm PCA media was pipetted. The mixture of the solution was vortexed and put in a sterile petri dish Petri dishes are carefully shaken until the sample is evenly mixed with the extract solution. The mixture is allowed to freeze in a petri dish. After that, the plates were incubated for 24 hours at room temperature $\left(27^{\circ} \mathrm{C}\right)$, the growth of the colonies in each cup was recorded, and the total plate count was calculated. Pollution of molds/yeast is carried out in the same way as the determination of TPN. In this test, Saboroud Dextrose Agar (SDA) is used as the agar media. SDA was dissolved with distilled water, then heated to a temperature of $45^{\circ} \mathrm{C}$ until bubbling, then put as much as $20 \mathrm{~mL}$ then sterilized at a temperature of $121^{\circ} \mathrm{C}$ for 15 minutes. A total of $1000 \mu \mathrm{L}$ from each dilution of the solution containing the warm SDA media was pipetted, then the mixture of the solution was vortexed and put in a sterile petri dish. The petri dish is gently rocked until the sample, and extract solution is thoroughly mixed, then left until the mixture is frozen in the petri dish. After that, it is put in the incubator cupboard for 3-5 days at room temperature $\left(27^{\circ} \mathrm{C}\right)$ in an upside-down position, then the yeast fungus number (YFN) is calculated in the sample.

\section{Results and Discussions}

Specific parameters

Specific parameters include levels of soluble extracts in ethanol and water, analysis of the content of extract compounds and propolis fraction, determination of total phenolic levels, determination of 
flavonoid levels, qualitative and semi-quantitative test content of ethanolic propolis extract compounds taken from 3 harvests with months that can be presented in Table 1.

Table 1. Specific parameters of ethanol extract of propolis $(n=3)$ obtained from 3 harvests in different months

\begin{tabular}{cll}
\hline No & Parameters & Results obtained \\
\hline 1 & Physical appearance & semi-solid \\
2 & Color & dark brown \\
3 & Odor & not typical \\
4 & Taste & bitter \\
5 & Water soluble essence $(\%)$ & $0.42-0.59$ \\
6 & Ethanol soluble essence $(\%)$ & $12.39-16.79$ \\
7 & Total flavonoid levels $(\mathrm{mg} \mathrm{ER} / \mathrm{g})$ & $0.015-0.078$ \\
8 & Total phenol levels $(\mathrm{CA} / \mathrm{g})$ & $0.39-0.53 \mathrm{mg}$ \\
9 & Chromatogram pattern $(\mathrm{Rf})$ & $0.73-0.78$ \\
\hline
\end{tabular}

Table 1. showed that organoleptic testing the quality of physical propolis extract obtained the same results, namely dark brown colour, odourless and bitter taste. This data was obtained from 3 samples harvested at different months. The next specific parameter is the determination of levels of compounds dissolved in water and ethanol. Both of these solvents are solvents obtained and meet pharmaceutical requirements. This parameter can provide information in the form of the amount of compound content that can be extracted. The results of propolis extract using ethanol solvents obtained extracts in higher amounts. The chemical content test of propolis extract aims to find out the total content of active compounds in it, namely total flavonoids and phenols.

The content of these compounds is proven by identification by using thin-layer chromatography (TLC) which results in a chromatogram pattern as presented in Figure 1.
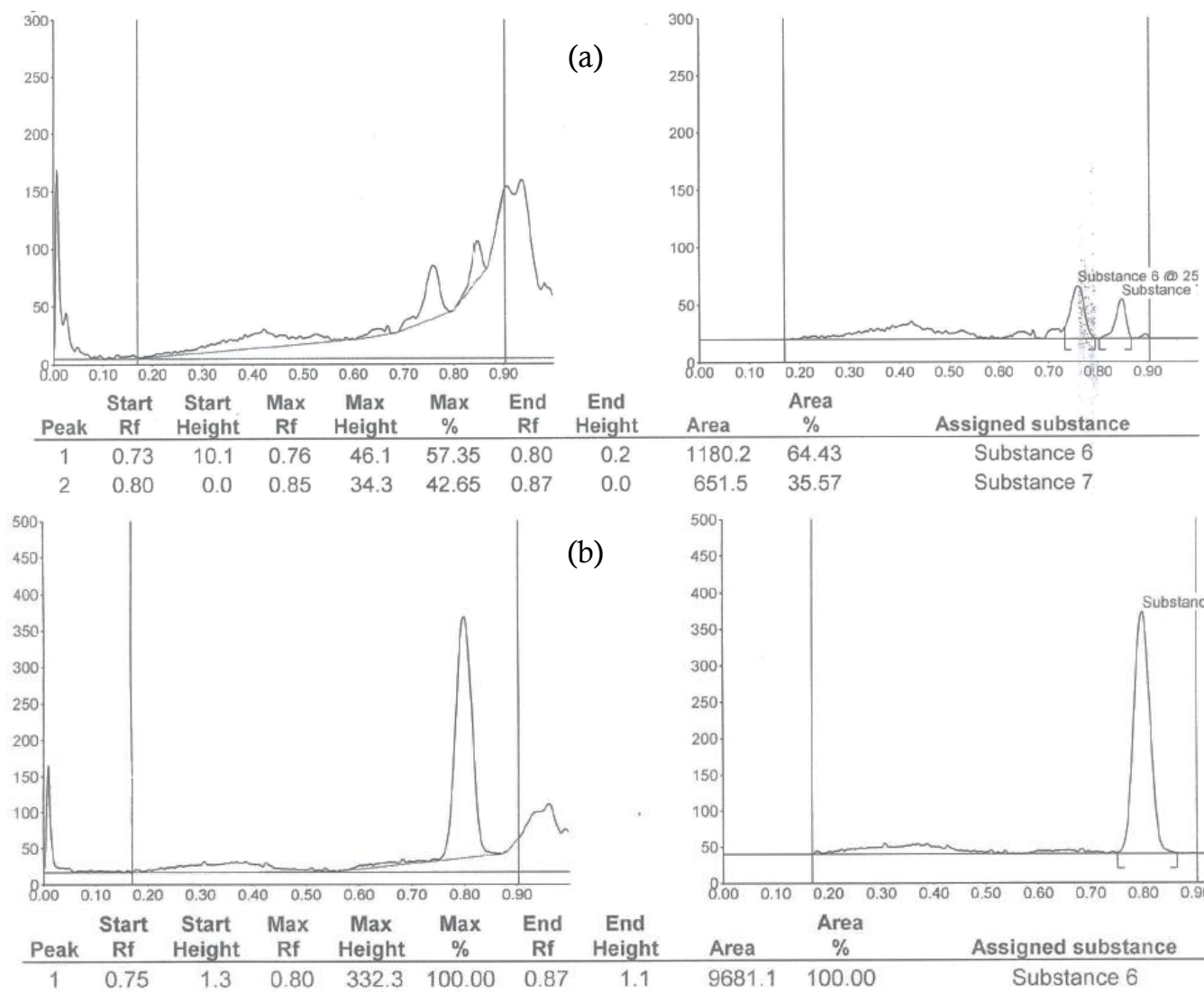

(b)

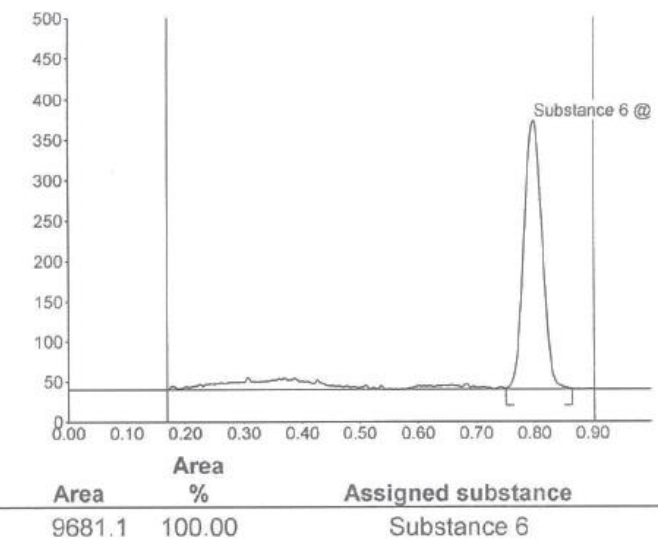

Figure 1. Chromatogram pattern of (a) propolis extract, (b) and caffeic acid as standard 
Figure 1. showed that propolis extract containing caffeic acid was shown with a similar Rf value of 0.76 in the sample and 0.80 in the standard. In the sample, it is known that caffeic acid is the most abundant compound in the extract with a value of $64.43 \%$. Differences in $\mathrm{Rf}$ values less than 0.5 can be stated to have the same content between extract and standard.

TLC is a rapid sample screening technique to identify compounds contained in herbal products. This method has been used to determine phenolic compounds, flavonoids, tannins and saponins in an extract containing herbal product formulations [16]. This technique is still widely used because it is economical and easy to use. The latest development of this tool shows results with a right level of reproducibility, resolution and sensitivity [17]. The data as Figure 1 strongly supports that the compounds contained in propolis contain caffeic acid with the same $\mathrm{Rf}$ results

Non-specific parameters

Non-specific characteristics which include determination of water content, determination of loss on drying, and determination of total ash content and acid-soluble ash levels as presented in Table 2. Measurement of water content in a material is needed in various fields, especially in an extract derived from the plant. High levels of water can cause mould growth. The water content in all samples is $10.24-10.61 \%$. Measurement of this level is set aside to avoid the rapid growth of fungi in the extract as well as to maintain the quality of the extract.

Table 2. Non-specific parameters of propolis ethanol extract $(n=3)$ taken from 3 harvests in different months

\begin{tabular}{cll}
\hline No & Parameters & Results obtained \\
\hline 1 & Water content $(\%)$ & $10.24-10.61$ \\
2 & Loss on drying $(\%)$ & $10.05-10.63$ \\
3 & Total ash content $(\%)$ & $0.10-0.65$ \\
4 & Acid soluble ash levels $(\%)$ & $0.20-0.70$ \\
5 & Specific gravity & 0.88 \\
6 & Pb content $(\mathrm{mg} / \mathrm{kg})$ & $0.15-0.20$ \\
7 & Cd content $(\mathrm{mg} / \mathrm{kg})$ & 0 \\
8 & Cu content $(\mathrm{mg} / \mathrm{kg})$ & $0.06-0.10$ \\
9 & TPN (colony $/ \mathrm{g})$ & $1-8.2 \times 10^{1}$ \\
10 & YFN (colony $/ \mathrm{g})$ & $1-1.3 \times 10^{1}$ \\
\hline
\end{tabular}

Determination of drying losses on the extract is one of the requirements that must be met in the quality test of medicinal plants. The results of the drying shrinkage test for samples 1,2 and 3 are in the range of $10.05-10.63 \%$. Knowing the drying loss can provide a maximum limit (range) about the amount of compound lost in the drying process [15].

Ash is an organic substance leftover from the combustion of organic material. Ash content depends on the type of material and how it is ignited. Ash content itself has to do with minerals which can be organic and inorganic salts. Ash content is essential because it can show the feasibility of a sample for further processing. Determination of ash content aims to provide an overview of internal and external mineral content that originates from the initial process until the formation of extracts with the principle of the extract is heated until organic compounds, and their derivatives are structured and evaporated until the only mineral and organic elements remain. The total ash content of samples 1, 2 and 3 is in the range of $0.10-0.65 \%$, while the acid insoluble ash content of samples 1,2 and 3 is in the range of $0.20-0.70 \%$. The total ash content in each propolis extract shows that the extract obtained from the maceration process contained minerals. While the acid insoluble ash content indicates the presence of sand or other impurities that still exist. Determination of ash content is used to determine the mineral content in extracts and mineral content which is not soluble in acids where the maximum range is related to purity and contaminants.

Specific weight is the ratio of the density of a substance to the density of water with the value of the mass unit volume $(\mathrm{m} / \mathrm{v})$. Determination of specific gravity aims to describe the chemical content dissolved in the extract (Depkes, 2000). The specific gravity of the propolis extracts of samples 1,2 and 3 was in the range of $0.8780-0.8898 \mathrm{~g} / \mathrm{mL}$. These results illustrate the amount of unity of the volume to provide a boundary between liquid extracts and thick extracts, besides also specific gravity related to how to determine the purity of a substance determined by its specific gravity [15]. 
This test aims to determine the levels of metal content $(\mathrm{Pb}, \mathrm{Cd}$, and $\mathrm{Cu})$ in propolis extract so that it can guarantee that the extract does not contain metals beyond the established limit because it is dangerous and is toxic to the body. The levels of $\mathrm{Pb}, \mathrm{Cu}$ and $\mathrm{Cd}$ in propolis extracts as in Table 2 were respectively in the range of $0.15-0.20 \mathrm{mg} / \mathrm{kg} ; 0 \mathrm{mg} / \mathrm{kg}$ and $0.06-0.10 \mathrm{mg} / \mathrm{kg}$. The maximum limit of heavy metal contamination in food refers to the metal contamination in honey because it is the closest product to propolis extract based on SNI 7387 of 2009, states that the maximum limit value for $\mathrm{Pb}$ metal content is 2 $\mathrm{mg} / \mathrm{kg}, \mathrm{Cd}$ metal does not exceed $0.2 \mathrm{mg} / \mathrm{kg}$, and $\mathrm{Cu}$ metal content of not more than $5 \mathrm{mg} / \mathrm{kg}$ as stipulated in the 2004 Indonesian National Standard on honey. Lead, cadmium levels for the three propolis extract samples exceeded the set limits. The high levels of $\mathrm{Pb}$ and $\mathrm{Cd}$ metals in the three samples can be influenced by several factors such as soil quality and air quality in the beekeeping area, as well as the use of metal tools that can cause contamination from the initial processing to the formation of samples. The high metal content in the soil media where the growth of plants consumed by bees will affect the quality of the raw propolis produced. Heavy metals can pollute the environment generally comes from motor vehicle fumes. To minimize the metal content in the sample can be done by controlling the quality of soil and air in the bee cultivation area, beekeeping should be far from urban areas with high air pollution and avoid the use of tools (containers) of metal material that can contaminate the sample. $\mathrm{Pb}$ and $\mathrm{Cd}$ metals are toxic to the body because, in the body, these metals can react to form complex bonds with ligands that contain elements $\mathrm{O}, \mathrm{S}$, and $\mathrm{N}$ [18]. While the $\mathrm{Cu}$ metal content for the three samples is below the specified level. $\mathrm{Cu}$ metal is an essential metal that is needed by the body in small amounts, $0.8 \mathrm{mg}-1.3$ $\mathrm{mg}$ [19], but if the amount exceeds a predetermined limit, this metal will also be toxic to the body.

Microbial contamination testing is one of the tests for the purity of extract requirements. This test includes determining the number of microorganisms that are allowed and to show the absence of certain bacteria in the extract. Microbial contamination test was seen from the presence of bacteria (Total Plate Number) and yeast moulds (Yeast Fungi Number) in each sample. The number of microbes is expressed in units of colonies/gram. Bacterial colonies in preparations that can be calculated are preparations containing colonies ranging from 25-250 colonies. able 2 shows the total plate numbers and mould numbers of yeast propolis extract samples 1, 2, and 3 have met the requirements of the total plate number values because they are below the maximum limit for "honey" because it is the closest product to propolis extract, whereas for the amount of mould numbers yeast for samples 1 and 2 have fulfilled the requirements while for sample 3 they have not met the criteria for honey that have been determined by BPOM RI Number HK.00.06.1.52.4011 concerning Determination of the Maximum Limit of Microbial and Chemical Contamination in Food for honey that is for TPN not more than 5103 colonies/g and for YFN no more than1 101 colony/g [20].

Media pollution can occur during the processing of the sample until the extract is obtained and can also be caused by the extract storage process. The amount of bacterial growth that is classified as low can be influenced by the content of antimicrobial substances contained in the extract used so that it can inhibit the number of bacteria (microbial) growth in the extract. The high YFN in sample 3 is due to the high of water content in the sample, if the amount of water content in a material is high, it will cause the growth of fungi that are harmful to health. In the TPN test no microscopic characteristics of Aspergillus flavus were found, which if the positive extract contained aflatoxin, the resulting colonies were very bright yellowishgreen on their growth media, whereas colonies that grew on white media. Therefore, the determination of aflatoxin numbers in this study was not carried out. Aflatoxins are brightly coloured secondary metabolites produced by the fungus Aspergillus flavus. This aflatoxin can cause toxigenic, mutagenic, teratogenic, and carcinogenic [20].

\section{Conclusion}

Propolis extract can be used as a raw material preparation from natural ingredients and has met several specific criteria that indicate all three samples have the same physical quality. Water-soluble sari content 0.42-0.59\%; ethanol-soluble extract levels $12.39-16.79 \%$; total flavonoid levels $0.015-0.078 \mathrm{mg}$ ER/ $\mathrm{g}$; total phenol levels from 0.39 to $0.53 \mathrm{mg} \mathrm{CA} / \mathrm{g}$; and the chromatogram pattern showed the extract 
contained caffeic acid. The results of the non-specific parameter quality test of propolis extract for the three samples fulfilled the requirements which were parameters of water content, metal contamination, total ash content, acid insoluble ash content, and microbial contamination.

\section{Acknowledgement}

The author thanks the Ministry of Research, Technology and Higher Education for funding this research with a contract number: 002/ST-DirDPPM/70/DPPM/PEN.TERAPAN UPTKEMRISTEKDIKTI/III/2019).

\section{References}

[1] J. M. Sforcin, V. Bankova, Propolis: Is There a Potential for the Development of New Drugs?, Journal of Ethnopharmacology 133 (2) (2011), 253-260.

[2] M.V. M das Neves, T. M. S da Silva, O. de E. Lima, E. V. L da Cunha, E. de J Oliveira, Isoflavone Formononetin from Red Propolis Acts as a Fungicide against Candida Sp. Braz., Journal of Microbiology 47 (1) (2016) , 159-166.

[3] S. Almutairi, R. Edrada-Ebel, J. Fearnley, J. O. Igoli, W. Alotaibi, C. J. Clements, A. I Gray, D. G Watson, Isolation of Diterpenes and Flavonoids from a New Type of Propolis from Saudi Arabia, Phytochemistry Letter 10 (2014), 160-163.

[4] G. Valenzuela-Barra, C. Castro, C. Figueroa, A. Barriga, X. Silva, B. de las Heras, S. Hortelano, C. Delporte, Anti-Inflammatory Activity and Phenolic Profile of Propolis from Two Locations in Región Metropolitana de Santiago, Chile, Journal of Ethnopharmacology 168 (2015) , 37-44.

[5] K. Wang, L. Hu, X. L. Jin, Q. X. Ma, M. C Marcucci, A. A. L Netto, A. C. H. F. Sawaya, S. Huang, W. K Ren, M. A. Conlon; et al., Polyphenol-Rich Propolis Extracts from China and Brazil Exert Anti-Inflammatory Effects by Modulating Ubiquitination of TRAF6 during the Activation of NF-kB, Journal of Functional Foods 19 (2015) , 464-478.

[6] N. Paulino, S. R. L. Abreu, Y. Uto, D. Koyama, H. Nagasawa, H. Hori, V.M. Dirsch, A. M. Vollmar, A. Scremin, W. A. Bretz, Anti-Inflammatory Effects of a Bioavailable Compound, Artepillin C, in Brazilian Propolis, European Jounal Pharmacology 587 (1-3) (2008) , 296-301.

[7] D. A. Sampietro, M. M Sampietro Vattuone, M. A Vattuone. Immunomodulatory Activity of Apis Mellifera Propolis from the North of Argentina, LWT - Food Science and Technology 70 (2016) , 915.

[8] G. Fischer, G, F. R. Conceição, F. P. L. Leite, L. A. Dummer, G. D. Vargas, S. de O Hübner, O. A. Dellagostin, N. Paulino, A. S. Paulino, T. Vidor, Immunomodulation Produced by a Green Propolis Extract on Humoral and Cellular Responses of Mice Immunized with SuHV-1, Vaccine, 25 (7) (2007), 1250-1256.

[9] Z. Hasan. Antibacterial Activity of Propolis Trigona Spp. from Bukittinggi West Sumatera Against Salmonella Sp, Chemistry Progress 4 (2) (2011).

[10] R. A. Laskar, N. Roy, N. A. Begum, Antioxidant Activity of Indian Propolis and Its Chemical Constituents, Food Chemistry 122 (1) (2010), 233-237.

[11] L. A. Elissa, N. M. Elsherbiny, A. O. Magmomah, Propolis Restored Adiponectin Level in Type 2 Diabetes through PPARy Activation, Egyptian Journal of Basic and Applied Sciences 2 (4) (2015), 318-326.

[12] S. M. Osés, A. Pascual-Maté, M. A. Fernández-Muiño, T. M. López-Díaz, M. T. Sancho, Bioactive Properties of Honey with Propolis, Food Chemistry 196 (2016), 1215-1223.

[13] I. A. Freires, S. M. de Alencar, P. L. A Rosalen, Pharmacological Perspective on the Use of Brazilian Red Propolis and Its Isolated Compounds against Human Diseases. European Journal of Medicinal Chemistry 110 (2016), 267-279.

[14] K. Graikou, M. Popova, O. Gortzi, V. Bankova, I. Chinou, Characterization and Biological Evaluation of Selected Mediterranean Propolis Samples. Is It a New Type?, LWT - Food Science and Technology 65 (2016), 261-267.

[15] Anonymous, General Standard Parameters of Drug Plant Extract, Department of Health Republic of Indonesia, Jakarta, 2000.

[16] S. K. Dinakaran, S. Chelle, H. Avasarala, Profiling and Determination of Phenolic Compounds in Poly Herbal Formulations and Their Comparative Evaluation, Jornal of Traditional and Complementary Medicine 9 (4) (2019), 319-327. 
[17] A. Bansal, V. Chhabra, R. K. Rawal, S. Sharma, Chemometrics: A New Scenario in Herbal Drug Standardization, Journal of Pharmaceutical Analysis 4 (4) (2014), 223-233.

[18] Z. Alfian, Analisis Kadar Logam Kadmium (Cd2+) Dari Kerang Yang Diperoleh Dari Daerah Belawan Secara Spektrofotometer Serapan Atom. Jurnal Sains dan Kimia 9 (2) (2005), 73-76.

[19] Anonim, Peraturan Kepala Badan Pengawas Obat Dan Makanan Republik Indonesia Nomor 12 Tahun 2014 Tentang Acuan Label Gizi, BPOM Republik Indonesia, Jakarta, 2016.

[20] Anonim, Batas Maksimum Cemaran Logam Berat Dalam Pangan, SNI 7389; 2009. 